\title{
Multidrug Resistant Enterobacteriaceae Isolates in Gastrointestinal Surgery Center
}

\section{Dina Mohi Eldin Abdelghafar Elhawary, Noha Badr Edeen El Mashad, Ahmed Abdel Rouf Elgeidie, Mohamed Mofreh* and Heba Abdelhameed Elshahawy}

\author{
Department, Faculty of Medicine, Mansoura University, Egypt
}

*Corresponding author

\section{A B S T R A C T}

Keywords

Multidrug

Resistant,

Enterobacteriaceae,

Klebsiella

pneumoniae

Article Info

Accepted:

04 December 2020

Available Online:

10 January 2021
The emergence and spread of antibiotic resistance, as well as the evolution of new strains of disease causing agents, are of great concern to the global health community. According to the European Centre for Disease Prevention and Control, MDR is defined as insusceptibility to at least one agent in three or more of the specified antimicrobial categories used in treatment. Since an effective treatment should be administered as soon as possible, resistance to many antimicrobial classes reduces the probability of adequate empirical coverage, with unfavorable consequences. In this study to investigate the phenotypic and genotypic characteristics of multidrug resistant Enterobacteriaceae in Mansoura Gastrointestinal Surgery Center, Egypt. A total of 99 multidrug resistant Enterobactericea isolates were included in this study. Antibiotic susceptibility testing using Vitek 2 system was done .Subsequent detection of different $\beta$-lactam and carpabenem resistance genes was done using conventional PCR method. 99 MDR isolates were selected from 641 gram negative bacterial samples depending upon that the isolates were non susceptible to $\geq 1$ agents in $>3$ antimicrobial categories. The most frequent isolated organisms were Klebsiella pneumoniae 27 (27.3\%). The distribution of resistant genes was 19 for TEM gene, 17 for SHV and OXA-23, 15 for VIM gene, and 4for IMP in the 99 isolate.

\section{Introduction}

The ongoing spread of multidrug-resistant organisms is compounded by the constant emergence of novel multidrug resistance profiles, causing severely limiting therapeutic options (Marston et al., 2016).

Enterobacteriaceae are significant causes of serious infections, and many of the most important members of this family are becoming increasingly resistant to currently available antibiotics (Bush, 2017).

Center for Disease Control and Prevention conservatively estimates that at least 23,000 people die annually in the USA as a result of an infection with an antibiotic-resistant organism (Munita and Arias, 2016)

Resistance associated with releasing of carbapenemases and extended-spectrum beta- 
lactamases (ESBLs) is a main problem in the treatment of Enterobacteriaceae infections. The carbapenemases emergence in Enterobacteriaceae is of specific concern because these bacteria are mostly associated with extensive drug resistance (XDR) and occasionally even pan-drug resistance (PDR) (Bush, 2017).

Resistance to antibiotics is a problem in community and hospital settings. The fast recognition in the clinical laboratories is necessary for the cautious identification of antimicrobial resistant (AMR) organisms. Extensive antibiotics consumption has been the critical pressure inducing the drugresistance, resulting in the worldwide concern of multi-AMR organisms. Much attention is given to infections by multidrug-resistant (MDR) organisms in very ill patients in the intensive care units (Khosravi et al., 2019).

Of special importance is resistance to carbapenems, which is caused mainly bycarbapenemase production combined with the expression extended-spectrum betalactamase (ESBL). The most prevalent carbapenemases in Enterobacteriaceae are KPC, VIM, NDM, and OXA (Kaose et al., 2012).

Extended-spectrum B-lactamases (TEM-, SHV) and carbapenemases are increasingly reported in Gram-negative bacilli (GNB). Since ESBL-producing bacteria are often multidrug resistant (MDR), carbapenems represent the last resort for life-threatening infections due to these organisms. Although several mechanisms of carbapenem resistance have been reported, most of the mechanisms are related to the spread of carbapenemases (KPCs, VIMs, IMPs and OXA-48). These enzymes compromise the clinical efficacy of almost the whole armamentarium of antimicrobial drugs, leaving clinicians with only a limited number of antimicrobial agents
(Naas et al., 2011).

So in this study we aimed to investigate the phenotypic and genotypic characteristics of MDR Enterobacteriaceae in Mansoura Gastrointestinal Surgery Center, Egypt.

\section{Materials and Methods}

A total of $99 \mathrm{GN}$ clinical isolates collected from October 2018 to October 2019at Mansoura Gastrointestinal Surgery Center.

They were selected from routine cultures based on their resistance to three or more of the specified antimicrobial classes (Aminopenicillin / B-lactamase inhibitor, Cephalosporins, Monobactams, Carbapenems, Fluoroquinolones, Aminoglycosides and Polymyxins) those classes are the most frequently used in microbiology lab. In Mansoura Gastrointestinal Surgery Center, Egypt.

\section{Detection of antibiotic-resistance genes by conventional PCR}

Six resistant genes (bla VIM, blaIMP, bla TEM, blaSHV, bla OXA and bla KPC) were tested based on (Kaose et al., 2012; Naas et al., 2011).

Genomic DNA was extracted from MDR clinical isolates by the boiling method (Ramadan et al., 2016) The extracted DNA was amplified by thermacycler.

For detection of $\beta$-lactamase-resistance genes ((blaTEM, blaSHVand bla KPC) metallo- $\beta$-lactamase resistance genes (blaIMP, blaVIM and blaOXA-23like). Sequences of the resistancegenes primers used in the study and the program of thermacycler (Thermo fisher scientific, Egypt) are provided in Table 1 and 2.

Amplicons were separated by $2 \%$ agarose-gel electrophoresis using a Gene Ruler 50 
and 100 bp ladder (Thermo Fisher Scientific) as a molecular size standard in each gel. Gels were stained with ethidium bromide and photographed under ultraviolet transillumination.

\section{Results and Discussion}

The tested resistance genes were TEM, SHV, IMP, VIM, KPC and OXA-23. TEM gene was detected in $19(19.2 \%)$ of all isolates followed by SHV, OXA-23 17 (17.2\% for each), VIM 15 (15.2\%), and the least frequent gene was IMP $4(4 \%)$ in the 99 isolate. KPC1 gene wasn't detected in any isolate of this study.

In the USA, the estimated healthcare cost associated to antimicrobial resistance (AMR) was $\$ 55$ billion per year in 2013 , and 2 million people were sick every year due to antibiotic-resistant infections, with over 23 000 deaths as a result (Dadgostar, 2019) (Fig. 1).

Table.1 Primers used for detection of resistance genes

\begin{tabular}{|c|c|c|c|c|}
\hline Primer & Sequence $\left(5^{\prime}-3^{\prime}\right)$ & Target gene & $\mathbf{T}_{\mathrm{a}}$ & Product size \\
\hline TEM-F & CATTTCCGTGTCGCCCTTATTC & \multirow{2}{*}{$\begin{array}{l}\text { TEM variants, } \\
\text { including TEM1 } \\
\text { andTEM2 }\end{array}$} & \multirow[t]{2}{*}{$60^{\circ} \mathrm{C}$} & \multirow[t]{2}{*}{800 bp } \\
\hline TEM-R & CGTTCATCCATAGTTGCCTGAC & & & \\
\hline SHV-F & AGCCGCTTGAGCAAATTAAAC & \multirow[t]{2}{*}{$\begin{array}{l}\text { SHV variants, } \\
\text { including SHV1 }\end{array}$} & \multirow[t]{2}{*}{$60^{\circ} \mathrm{C}$} & \multirow[t]{2}{*}{$713 \mathrm{bp}$} \\
\hline SHV-R & ATCCCGCAGATAAATCACCAC & & & \\
\hline IMP-F & TTGACACTCCATTTACDG & \multirow[t]{2}{*}{ IMP variants } & \multirow[t]{2}{*}{$55^{\circ} \mathrm{C}$} & \multirow[t]{2}{*}{$139 \mathrm{bp}$} \\
\hline IMP-R & GATYGAGAATTAAGCCACYCT & & & \\
\hline VIM-F & GATGGTGTTTGGTCGCATA & \multirow[t]{2}{*}{ VIM variants } & \multirow[t]{2}{*}{$55^{\circ} \mathrm{C}$} & \multirow[t]{2}{*}{$390 \mathrm{bp}$} \\
\hline VIM-R & CGAATGCGCAGCACCAG & & & \\
\hline $\begin{array}{l}\text { OXA-23- } \\
\text { like-F }\end{array}$ & GAT CGG ATT GGA GAA CCA GA & \multirow[t]{2}{*}{ OXA23-like } & \multirow[t]{2}{*}{$53^{\circ} \mathrm{C}$} & \multirow[t]{2}{*}{$501 \mathrm{bp}$} \\
\hline $\begin{array}{l}\text { OXA-23- } \\
\text { like-R }\end{array}$ & ATT TCT GAC CGC ATT TCC AT & & & \\
\hline KPCF & TGTCACTGTATCGCCGTC & \multirow[t]{2}{*}{ blaKPC-1 } & \multirow[t]{2}{*}{$63^{\circ} \mathrm{C}$} & \multirow[t]{2}{*}{$1010 \mathrm{bp}$} \\
\hline KPCR & CTCAGTGCTCTACAGAAAACC & & & \\
\hline
\end{tabular}

Table.2 Thermacycler program used for detection of resistance genes

\begin{tabular}{|c|c|c|c|c|c|}
\hline Gene & Activation & Denaturation & Annealing & Extension & $\begin{array}{c}\text { Final } \\
\text { extension }\end{array}$ \\
\hline TEM\&SHV & $95^{\circ} \mathrm{C}$ for $3 \mathrm{~min}$ & $95^{\circ} \mathrm{C}$ for $30 \mathrm{sec}$ & $\begin{array}{c}60^{\circ} \mathrm{C} \text { for } 30 \\
\mathrm{sec}\end{array}$ & $\begin{array}{c}72^{\circ} \mathrm{C} \text { for } 30 \\
\text { sec }\end{array}$ & $\begin{array}{l}10 \text { min at } \\
72^{\circ} \mathrm{C}\end{array}$ \\
\hline IMP\& VIM & $95^{\circ} \mathrm{C}$ for $2 \mathrm{~min}$ & $95^{\circ} \mathrm{C}$ for $30 \mathrm{sec}$ & $\begin{array}{c}55^{\circ} \mathrm{C} \text { for } 30 \\
\text { sec }\end{array}$ & $\begin{array}{c}72^{\circ} \mathrm{C} \text { for } 30 \\
\text { sec }\end{array}$ & $\begin{array}{l}10 \text { min at } \\
72^{\circ} \mathrm{C}\end{array}$ \\
\hline OXA-23 & $95^{\circ} \mathrm{C}$ for $2 \mathrm{~min}$ & $95^{\circ} \mathrm{C}$ for $30 \mathrm{sec}$ & $\begin{array}{c}53{ }^{\circ} \mathrm{C} \text { for } 30 \\
\text { sec }\end{array}$ & $\begin{array}{c}72{ }^{\circ} \mathrm{C} \text { for } 30 \\
\text { sec }\end{array}$ & $\begin{array}{l}10 \text { min at } \\
72^{\circ} \mathrm{C}\end{array}$ \\
\hline KPC & $95^{\circ} \mathrm{C}$ for $2 \mathrm{~min}$ & $95^{\circ} \mathrm{C}$ for $30 \mathrm{sec}$ & $\begin{array}{c}63{ }^{\circ} \mathrm{C} \text { for } 30 \\
\text { sec }\end{array}$ & $\begin{array}{c}72{ }^{\circ} \mathrm{C} \text { for } 30 \\
\text { sec }\end{array}$ & $\begin{array}{l}10 \text { min at } \\
72{ }^{\circ} \mathrm{C}\end{array}$ \\
\hline
\end{tabular}


Table.3 Frequency of the studied resistance genes among the selected (99) MDR isolates

\begin{tabular}{|l|l|l|}
\hline Gene & Frequency (No.) & Percentage (\%) \\
\hline TEM gene: & \multicolumn{2}{|l|}{} \\
\hline Negative (non-detectable) & 80 & 80.8 \\
\hline SHV gene: & \multicolumn{2}{l|}{} \\
\hline Negative (non-detectable) & 82 & 82.8 \\
\hline Positive (Detectable) & 17 & 17.2 \\
\hline IMP gene & \multicolumn{2}{|l|}{} \\
\hline Negative (non-detectable) & 95 & 96.0 \\
\hline Positive (Detectable) & 4 & 4.0 \\
\hline VIM gene: & \multicolumn{2}{|l|}{} \\
\hline Negative (non-detectable) & 84 & 84.8 \\
\hline Positive (Detectable) & 15 & 15.2 \\
\hline KPC gene: & \multicolumn{2}{|l|}{} \\
\hline Negative (non-detectable) & 99 & 100 \\
\hline Positive (Detectable) & 0 & 0 \\
\hline Oxa-23 gene: & \multicolumn{2}{|l|}{} \\
\hline Negative (non-detectable) & 82 & 82.8 \\
\hline Positive (Detectable) & 17 & 17.2 \\
\hline
\end{tabular}

Table.4 Distribution of studied resistance genes in the identified MDR organism

\begin{tabular}{|c|c|c|c|c|c|c|}
\hline Organism & TEM & SHV & IMP & VIM & KPC & Oxa-23 \\
\hline Klebsiella pneumonia (n=27) & $9(33.3 \%)$ & $7(25.9 \%)$ & $3(11.1 \%)$ & $4(14.8 \%)$ & $0(0 \%)$ & $6(22.2 \%)$ \\
\hline $\begin{array}{c}\text { Acinetobacter baumannii } \\
(\boldsymbol{n = 2 5 )}\end{array}$ & $8(32 \%)$ & $8(32 \%)$ & $1(4 \%)$ & $9(36 \%)$ & $0(0 \%)$ & $9(36 \%)$ \\
\hline $\begin{array}{c}\text { E. coli }(\boldsymbol{n = 2 3 )} \\
\text { Enterobacter cloacae (n=8) }\end{array}$ & $1(4.3 \%)$ & $0(0 \%)$ & $0(0 \%)$ & $1(4.3 \%)$ & $0(0 \%)$ & $1(4.3 \%)$ \\
\hline $\begin{array}{c}\text { Pseudomonas aeruginosa } \\
(\boldsymbol{n}=\mathbf{6})\end{array}$ & $1(16.7 \%)$ & $1(12.5 \%)$ & $0(0 \%)$ & $0(0 \%)$ & $0(0 \%)$ & $0(0 \%)$ \\
\hline $\begin{array}{c}\text { Proteus mirabilis }(\mathbf{n = 6}) \\
\text { Citrobacterfreundii }(\mathbf{n = 4})\end{array}$ & $0(0 \%)$ & $0(0 \%)$ & $0(0 \%)$ & $0(0 \%)$ & $0(0 \%)$ & $0(0 \%)$ \\
\hline
\end{tabular}

Table.5 Frequency of the detected genes in each identified MDR isolates

\begin{tabular}{|c|c|c|c|c|}
\hline Organism & $\begin{array}{c}\text { No detected } \\
\text { genes }\end{array}$ & One gene & Two genes & $\begin{array}{c}\text { More than two } \\
\text { genes }\end{array}$ \\
\hline $\begin{array}{c}\text { Klebsiella pneumonia } \\
(16 / 27)\end{array}$ & 11 & $9(56.2 \%)$ & $4(25 \%)$ & $3(18.7 \%)$ \\
\hline $\begin{array}{c}\text { Acinetobacter baumannii } \\
(\mathbf{1 6 / 2 5 )}\end{array}$ & 9 & $6(37.5 \%)$ & $5(31.2 \%)$ & $5(31.2 \%)$ \\
\hline $\begin{array}{c}\text { E. coli } \mathbf{( 2 / 2 3 )} \\
\text { Enterobacter cloacae (1/8) }\end{array}$ & 21 & $1(50 \%)$ & $1(50 \%)$ & - \\
\hline $\begin{array}{c}\text { Pseudomonas aeruginosa } \\
(\mathbf{1 / 6 )}\end{array}$ & 5 & $1(100 \%)$ & - & - \\
\hline
\end{tabular}


Table.6 Distribution of detected genes in relation to different antibiotic class

\begin{tabular}{|l|c|c|c|c|c|}
\hline \multicolumn{1}{|c|}{ Antibiotic } & $\begin{array}{c}\text { TEM } \\
(\mathbf{n = 1 9})\end{array}$ & $\begin{array}{c}\text { SHV } \\
(\mathbf{n = 1 7})\end{array}$ & $\begin{array}{c}\text { IMP } \\
(\mathbf{n = 4})\end{array}$ & $\begin{array}{c}\text { VIM } \\
(\mathbf{n = 1 5})\end{array}$ & $\begin{array}{c}\text { Oxa-23 } \\
(\mathbf{n = 1 7})\end{array}$ \\
\hline $\begin{array}{l}\text { Aminopenicillin / B-lactamase } \\
\text { inhibitor (n=30) }\end{array}$ & $9(30 \%)$ & $5(16.7 \%)$ & $3(10 \%)$ & $4(13.3 \%)$ & $5(16.7 \%)$ \\
P value & 0.096 & 1.000 & 0.082 & 1.000 & 1.000 \\
\hline Cephalosporins (n=99) & 19 & 17 & $4(4 \%)$ & 15 & $17(17.2 \%)$ \\
& $(19.2 \%)$ & $(17.2 \%)$ & & $(15.2 \%)$ & \\
\hline $\begin{array}{l}\text { Monobactams (n=78) } \\
\text { P value }\end{array}$ & 16 & 17 & $3(3.8 \%)$ & 14 & $16(20.5 \%)$ \\
\hline Carbapenems (n=74) & $(20.5 \%)$ & $(21.8 \%)$ & 1.000 & $(17.9 \%)$ & 0.111 \\
P value & 0.756 & $\mathbf{0 . 0 2 0}$ & & 0.182 & \\
& 18 & 15 & $4(5.4 \%)$ & 15 & $15(20.3 \%)$ \\
\hline $\begin{array}{l}\text { Fluoroquinolones (n=91) } \\
\text { P value }\end{array}$ & $(24.3 \%)$ & $(20.3 \%)$ & 0.569 & $(20.3 \%)$ & 0.225 \\
& $\mathbf{0 . 0 3 7}$ & 0.225 & & $\mathbf{0 . 0 1 0}$ & $17(18.7 \%)$ \\
\hline $\begin{array}{l}\text { Aminoglycosides (n=22) } \\
\text { P value }\end{array}$ & $(20.9 \%)$ & $(19.7 \%)$ & 1.000 & $(16.5 \%)$ & 0.344 \\
\hline Polymyxins (n=99) & 0.347 & 0.344 & & 0.603 & $7(31.8 \%)$ \\
\hline
\end{tabular}

Fig.1 Flow chart of different clinical sample processing from October 2018 to October 2019: Isolates that expressed MDR on Muller Hinton agar disc diffusion were retested by VITEK 2. The selection of these isolates was based on antibiogram results according to CLSI recommendations (CLSI, 2017)

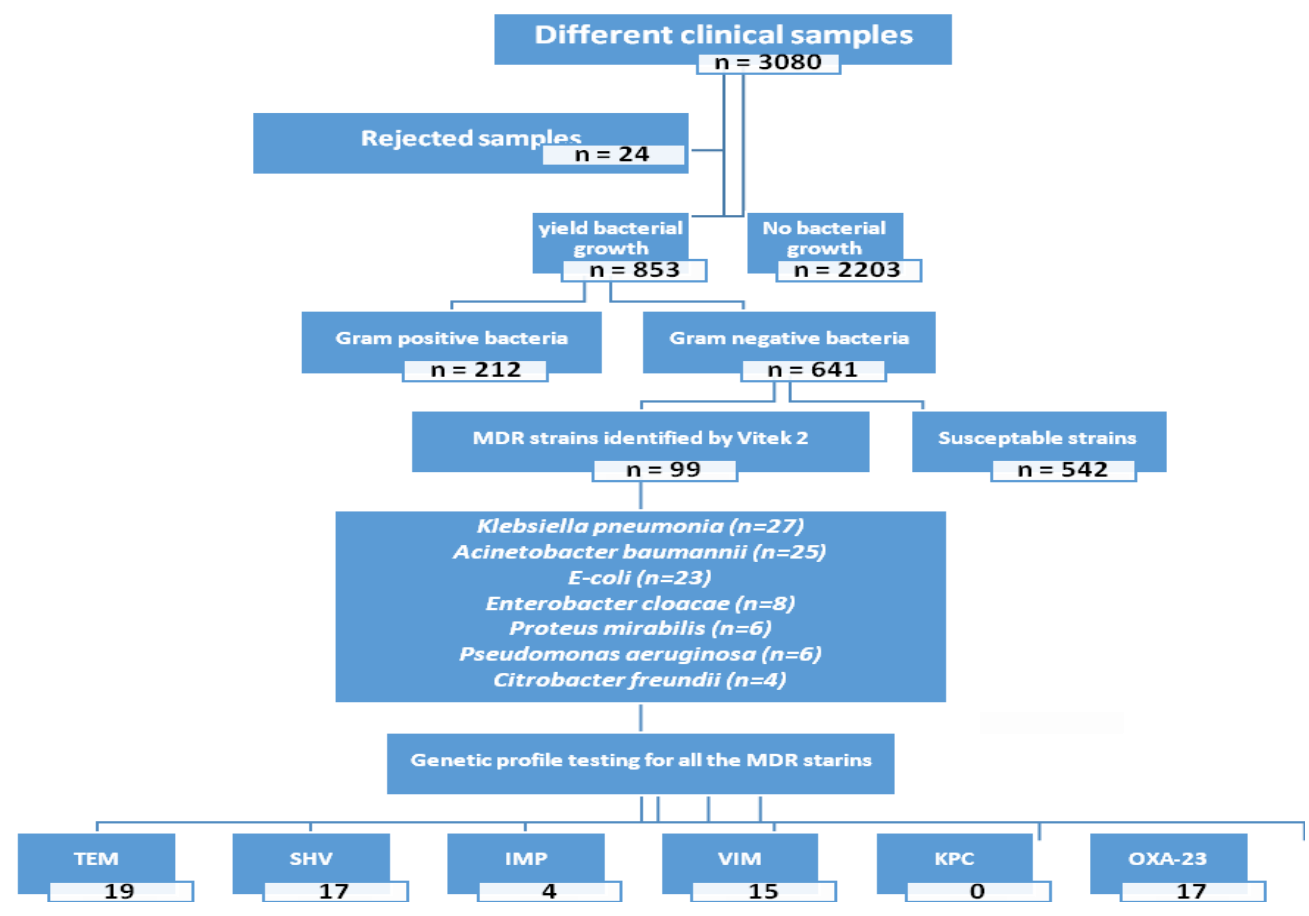


Carbapenems and Extended-spectrum $\beta$ lactams have been generated as particular agents to manage the bacterial infections non susceptible to penicillins. The resistance of Bacteria to carbapenems involves also the resistance to other $\beta$-lactams. Consequently, carbapenems resistance is an important threat to cases that are susceptible to infections resulted from MDR bacteria all over the world. In different species of bacteria, new (ESBLs) or carbapenemases with characteristic features or dissimilar structures are documented every year (Sawa et al., 2020). 99 Enterobacteriaceae isolate resistant to three or more classes of antibiotics were included in this study over a period of one year from October 2018 to October 2019. They were identified as: Klebsiella pneumonia 27 (27.3\%) was the most frequent isolated organism followed by Acinetobacter baumannii 25 (25.3\%), E-coli 23 (23.2\%), Enterobactercloacae 8 (8.1\%), Proteus mirabilis $6(6.1 \%)$ then Pseudomonas aeruginosa6 $(6.1 \%)$ and the least frequent isolate was Citrobacter freundii 4 (4.0\%).

The tested resistance genes were TEM, SHV, IMP, VIM, KPC and OXA-23. TEM gene was detected in $19(19.2 \%)$ of all isolates followed by SHV, OXA-23 17 (17.2\% for each), VIM 15 (15.2\%), and the least frequent one was IMP $4(4 \%) . K P C 1$ gene wasn't detected in any isolate of this study (Table 3).

In contrast to the study was done by Helmy and Kashef (2017), who performed a study on 118 isolate stated that $b l a_{\mathrm{TEM}-1}$ gene was frequent in the isolates of MDR Enterobacteriaceae and was the only revealed gene of $\beta$-lactamase-resistance in $6 \%$ of them. The gene of $\beta$-lactamase-resistance (blaSHV) was revealed in $28.3 \%$ of MDR Enterobacteriaceae.

Abouelfetouh et al., (2019) performed a study on 74 Carbapenem-resistant Acinetobacter baumannii (CR-AB) isolates, from different clinical specimens collected from the lab of microbiology at Alexandria Main University Hospital, Egypt and stated that $\left(b l a_{K P C}\right.$ nor bla $_{I M P}$ ) were not revealed in any of the examined isolates while bla $a_{V I M}$ was detected in $74(100 \%)$. Beta-lactamases production is thought to be the most common resistance mechanism that contributes to widespread resistance among GNB. > 200 variable types of (ESBLs) were documented all over the world so far; they were mostly recognized in the family of Enterobacteriaceae (Rahman et al., 2018).

In our study Acinetobacter baumannii and Klebsiella pneumoniae were the most isolates expressing resistance genes, however Proteus mirabilis and Citrobacter freundii did not express any of studied resistance genes (Table 4). Multidrug resistant enterobactericea is a major problem in GISC (it represents 15\% from total G-ve bacteria and $11.6 \%$ of all infection) in the period frm October 2018 to October 2019. The most frequently detected genes in Klebsiella pneumonia (27) were TEM in $9(33.3 \%)$, SHV gene in $7(25.9 \%)$, Oxa-23 in $6(22.2 \%)$, VIM in $4(14.8 \%)$ and IMP in $3(11.1 \%)$ respectively.

While those in Acinetobacter baumannii (25) were VIM in $9(36 \%)$, Oxa-23 gene in 9 $(36 \%)$, TEM in $8(32 \%)$, SHV in $8(32 \%)$ and IMP in $1(4 \%)$ respectively. And those in $E$. coli (23) were TEM, VIM and Oxa -23 in 1 (4.3\% for each). While for Enterobacter cloacae the detected genes were $1(12.5 \%)$ SHV, where as Pseudomonas aeruginosa the genes were $1(16.7 \%)$ for TEM, SHV, VIM and Oxa-23(Table 4).

The most problematic recent occurrence is the apperance of several OXA enzymes in $A$. baumannii which give the resistance to $\mathrm{b}$ lactam (Adam and Elhag, 2018). 
In the study done by Safari et al., (2015) 100 Acinetobacter baumannii isolates have been examined for 3 ESBLs (CTX-M, SHV and TEM) and 5 MBLs encoding genes (VIM-Family, IMP-Family, SPM-1, SIM-1 and GIM-1). Three out of eight genes have been detected including SHV (58\%), TEM $(20 \%)$ and VIM $(30 \%)$. None of the other studied genes has been detected.

Jácome et al., (2016)found that blaTEM was identified in seven isolates of Acinetobacter spp. $(25.9 \%)$ and 11 isolates of Klebsiella spp. $(30.6 \%)$, but was not amplified in $P$. aeruginosa.

Adam and Elhag (2018) examined MBL genes by multiplex PCR among 200 Gram -ve clinical isolates at Khartoum hospitals in Sudan showed Verona integrin Metallo betalactamase (VIM) was the most frequently detected genes $(38.9 \%)$, then imipenemase (IMP) was (26.4\%).

In our study, a wide range of carbapenem resistance determining genes (blaVIM, blaIMP, blaKPC, OXA-23) were detected among different MDR-GNB isolates from patient specimens in Mansoura Gastrointestinal Surgery center.

Regarding the isolated Proteus mirabilis and Citrobacter freundii isolates that didn't exhibit any of the studied resistance genes this is attributed to other resistance mechanisms such as $i$ ) alterations of the antimicrobial target site, ii) a reduction in the uptake of the agent, iii) activation of efflux mechanisms to extrude the agent out the cell of microorganism, or $i v$ ) global alterations in significant metabolic pathways. Antibiotic resistance in these isolates may therefore be associated with other genes not examined in this study (Hu et al., 2014). 9 Klebsiella pneumoniae isolates (56.2\%) expressed single gene, $4(25 \%)$ expressed two genes while 3
(18.7\%) expressed more than two genes. 6 (37.5\%) of Acinetobacter baumannii isolates expressed single gene, $5(31.2 \%)$ expressed two genes and $5(31.2 \%)$ expressed more than two genes. E. coli isolates 1 (50\%) expressed one gene, 1 (50\%) expressed two genes. An Enterobacter cloacae isolates expressed single gene. Pseudomonas aeruginosa, isolates expressed $1(100 \%)$ more than two genes (Table 5).

Co-presence of dissimilar classes of genes of resistance was frequent among our isolates. This is alarming, because it offers an antibiotic selection advantage for these isolates to prevail as MDR (Helmy and Kashef, 2017).

Co-production of carbapenemases with other $\beta$-lactamases results in resistance to nearly all clinically available $\beta$-lactams and poses challenges for treatment of clinically significant infections caused by these organisms (Hu et al., 2014).

In Table 6, TEM and VIM genes were significantly expressed among the isolates that were resistant to Carbapenems $(\mathrm{P}=0.037$, $0.010)$ respectively. SHV gene was significantly expressed among the isolates that were resistant to monobactams and aminoglycosides $(\mathrm{P}=0.020)$.

Carbapenem-resistant Enterobacteriaceae (CRE) have been increasingly documented globally and have a significant public threat. The rising carbapenems resistant organisms have become a risk factor to existing antibiotics used for handling nosocomial infections (e.g. bacteremia, septicemia, and pneumonia in children) (Chiotos et al., 2017).

Carbapenems resistance may be caused by 3 main mechanisms: porin-mediated resistance to decrease the agent uptake, efflux pumps, that pump the agent out the cells and enzyme- 
mediated resistance that is mediated through the acquirement of the genes of carbapenemase. carbapenems Resistance among the MDR-GNB is often because of the carbapenemases production that are $\beta$ lactamases having the ability to hydrolyze the carbapenems and all the other beta lactam compounds (Elshamy and Aboshanab, 2020).

CDC and WHO have lately classified CPE as one of the most vital AMR threats. CPE rarely arise de novo; rather, colonization and infection take place as a consequence of transmission of organisms, plasmids, or transposons from subject to subject, with such transmission taking place in healthcare institutions. An understanding of the epidemiology of the emergence of CPE is important to the control programs implementation and the treatment of cases (Kohler et al., 2018).

In conclusion,

MDR organisms were strongly represented among gran negative bacterial isolates in Mansoura Gastrointestinal Surgery Center (15\% from total G-ve bacteria).

Isolated organisms showed $100 \%$ resistance to cephalosporins and $100 \%$ sensitivity to polymyxins.

Acinetobacter baumannii and Klebsiella pneumonia were the most isolates expressing resistance genes and this alarming for infection control guidance to prevent the HAIs and the transmission of multidrug-resistant pathogens in hospitals.

bla TEM gene was the most resistance gene detected in GISC.

Isolation of MDRO (11.6\% of all infections) in our lab means we are facing an ever-increasing problem and dangerous limitations of treatment options and possibility of transmission between patients.

\section{Recommendations}

Implementing a mandatory antibiotic policy.

Proper infection measures and contact precautions are intended for patients infected with any MDRO.

Finally this study opens the door for wide scale studies on MDR Enterobactericea to clear out other genetic and non-genetic mechanisms of resistance.

\section{References}

Abouelfetouh, A., Torky,A., and Aboulmagd, E. 2019. Phenotypic and genotypic characterization of carbapenem-resistant Acinetobacter baumannii isolates from Egypt.Antimicrob Resist Infect Control. 8: 185.

Adam, M., and Elhag,W. 2018. Prevalence of metallo- $\beta$-lactamase acquired genes among carbapenems susceptible and resistant Gram-negative clinical isolates using multiplex PCR, Khartoum hospitals, Khartoum Sudan. BMC Infect Dis. 18(1):668.

Bush, K. 2017. The Importance of $\beta$-Lactamases to the Development of New $\beta$-Lactams In: D. Mayers, J. Sobel, M. Ouellette, K. Kaye and D. Marchaim (eds.), Antimicrobial Drug Resistance. Springer: Cham, Switzerland, pp.165 - 176.

Chiotos., K., Han, J., and Tamma, P.D. 2017. Carbapenem-Resistant Enterobacteriaceae Infections in Children. Curr Infect Dis Rep. 18(1): 2.

CLSI, 2017. CATALOG 2017/2018. www.clsi.org Dadgostar, P. 2019. Antimicrobial Resistance: Implications and Costs. Infect Drug Resist. 12: 3903-3910.

Elshamy, A. A., and Aboshanab, K.M. 2020. A review on bacterial resistance to carbapenems: epidemiology, detection and treatment options. Future Sci OA. 6(3): FSO438.

Helmy, O., and Kashef, M. 2017. Different phenotypic and molecular mechanisms 
associated with multidrug resistance in Gram-negative clinical isolates from Egypt. Infect Drug Resist. 10: 479-498.

Hu, L., Zhong, Q., Shang, Y., Wang, H., Ning, C., Li, Y., Hang, Y., Xiong, J., Wang, X., Xu, Y., Qin, Z., Parsons, C., Wang,L., and Yu, F. 2014. The prevalence of carbapenemase genes and plasmidmediated quinolone resistance determinants in carbapenem-resistant Enterobacteriaceae from five teaching hospitals in central China. Epidemiol Infect. 142 (9): 1972-1977.

Jácome, P.R.L.D.A., Alves, L.R., Jácome-Júnior, A.T., Silva, M.J.B.D., Lima, J..L.d.C., Araújo, P.S.R., Lopes, A.C.S., and Maciel, M.A.V. 2016. Detection of blaSPM-1, blaKPC, blaTEM and blaCTX$\mathrm{M}$ genes in isolates of Pseudomonas aeruginosa, Acinetobacter spp. and Klebsiella spp. from cancer patients with healthcare-associated infections. J Med Microbiol. 65(7): 658-665.

Kaase, M., Szabados, F., Wassill,L. and Gatermann, S. 2012. Detection of Carbapenemases in Enterobacteriaceae by a Commercial Multiplex PCR. J Clin Microbiol. 50 (9): 3115-3118.

Khosravi, A., Taee, S., Dezfuli, A., Meghdadi, H., and Shafie, F. 2019. Investigation of the prevalence of genes conferring resistance to carbapenems in Pseudomonas aeruginosa isolates from burn patients. Infect Drug Resist. 12: 1153 - 1159.

Kohler, P.P., Melano, R.G., Patel, S.N., Shafinaz, S., Faheem, A., Coleman, B.L., Green, K., Armstrong, I., Almohri, H., Borgia, S., Borgundvaag, E., Johnstone, J., Katz, K., Lam, F., Muller, M.P., Powis, J., Poutanen, S.M., Richardson, D., Rebbapragada, A., Sarabia, A., Simor,A. and McGeer, A. 2018. Emergence of Carbapenemase-Producing Enterobacteriaceae, South-Central Ontario, Canada. Emerg Infect Dis. 24 (9): 16741682.

Marston, H., Dixon, D., Knisely J., Palmore, T., and Fauci, A. 2016. Antimicrobial Resistance. JAMA. 316(11): 1193 - 1204.

Munita, J., and Arias,C. 2016. Mechanisms of Antibiotic Resistance. Microbiol Spectr. 4(2):10.1128.

Naas, T., Cuzon, G., Bogaerts, P., Glupczynski, Y., and Nordmann, P. 2011. Evaluation of a DNA Microarray (Check-MDR CT102) for Rapid Detection of TEM, SHV, and CTX-M Extended-Spectrum -Lactamases and of KPC, OXA-48, VIM, IMP, and NDM-1 Carbapenemases. J Clin Microbiol. 49 (4): 1608-1613.

Rahman, S., Ali, T., Ali, I., Khan, N., Han, B., and Gao, J. 2018. The growing genetic and functional diversity of extended spectrum beta-lactamases. Biomed Res Int. 2018:9519718

Ramadan, H., Awad, A., and Ateya, A. 2016. Detection of phenotypes, virulence genes and phylotypes of avian pathogenic and human diarrheagenic Escherichia coli in Egypt.J Infect Dev Ctries. 10(6): 584-591.

Safari, M., Nejad,A., Bahador, A., Jafari, R. and Alikhani, M. 2015. Prevalence of ESBL and MBL encoding genes in Acinetobacter baumannii strains isolated from patients of intensive care units (ICU). Saudi J Biol Sci. 22(4): 424-429.

Sawa T., Kooguchi, K., Moriyama,K. 2020. Molecular diversity of extended-spectrum $\beta$-lactamases and carbapenemases, and antimicrobial resistance $\mathbf{J}$ Intensive Care. 8: 13 .

\section{How to cite this article:}

Dina Mohi Eldin Abdelghafar Elhawary, Noha Badr Edeen El Mashad, Ahmed Abdel Rouf Elgeidie, Mohamed Mofreh and Heba Abdelhameed Elshahawy. 2021. Multidrug Resistant Enterobacteriaceae Isolates in Gastrointestinal Surgery Center. Int.J.Curr.Microbiol.App.Sci. 10(01): 242-250. doi: https://doi.org/10.20546/ijcmas.2021.1001.029 